\title{
TENDENCIES OF THE DEVELOPMENT \\ OF THE BUKOVYNIAN SCULPTURE FROM THE MIDDLE OF THE 20TH TO THE BEGINNING OF THE 21TH CENTURY
}

\section{Mishchenko I. I.}

\section{INTRODUCTION}

The art of Bukovyna of the middle of the 20th - the beginning of the 21 st centuries in general and sculpture, in particular, has been practically neglected by scientists. Few works devoted to the art of the region cover mostly the development of painting, so studying this problem one can only rely on individual publications, the majority of which are leaflets, catalogues, articles in magazines and encyclopedic publications. In this regard, the study of sculpture of this period is relevant for comprehensive coverage of the history of art of the region and the understanding of the artistic processes of the present in Ukraine.

The analysis of existing publications proves that the topic was not properly reflected in scientific works and popular science entries. Only single articles on the creative views of a sculptor are found, mostly in the periodicals of the region.

Among the publications are catalogs and brochures issued by the Chernivtsi Organization of the Union of Artists of Ukraine in 1970s 1980s on the occasion of holding regional or personal exhibitions, in particular, by T. Udina ${ }^{1}$ and K. Valigura ${ }^{2}$, which, as well as the 1998 edition of "Bukovynian Artists" 3 , contain biographical information about the artists. An exception forms the work of T. Dugayeva in which O. Shevchukevich's ${ }^{4}$ achievements are examined in detail.

1 Юрій Джибраєв : проспект виставки творів / авт.-упоряд. Т. Удіна, Є. Удін. Чернівці, 1970; Анатолій Скиба : проспект виставки творів / авт. Т. Удіна. Чернівці, 1970.

2 Анатолій Георгійович Скиба : каталог / авт. К. Валігура. Чернівці, 1980. 48 c.

${ }^{3}$ Митці Буковини : Енцикл. довід. / авт.-упоряд. Т. Дугаєва, І. Міщенко. Т. 1. Чернівці : Золоті литаври, 1998. 128 с.

4 Дугаєва Т. Скульптор, доктор медицини Опанас Шевчукевич. Чернівці : Зелена Буковина, 2002. 88 с. 
The creativity of contemporary sculptors is partly represented in the publications of the author of this article ${ }^{5}$ and the catalogs of various projects ${ }^{6}$, which mainly contain reproductions of works and brief data about them. However, there is no summarizing work that would illustrate the progress of plastics on the territory of Bukovyna; this confirms the need to study this issue.

The purpose of this study is to analyze the ways of development of Bukovynian sculpture from 1940 to 2019, to identify the patterns of appearance of stylistic changes in the plastics of the region, to introduce into scientific circulation a significant number of names and works of sculptors of the specified period, to highlight the manifestation features of various artistic trends in the works of different authors.

\section{Bukovynian sculpture from 1940 till mid $1980 s$}

The development of Bukovynian sculpture of the 20 th $-21^{\text {st }}$ centuries repeats in most of its manifestations the stages and features of the progress of the fine arts of the region of the mentioned period. Before talking about the plastics of the region, we should mention the processes that took place in the territory of Bukovyna and influenced its cultural and artistic development.

Being a border region, Bukovyna in general, as well as Northern Bukovyna (now - Chernivtsi region of Ukraine), was influenced by the neighboring nations, and the artistic process on its territory at the end of the 19 th - at the beginning of the 20th century were extremely dynamic. Due to the close links between individual artists and societies of Bukovyna and Europe, the artistic styles and trends of the latter became crucial for the development of architecture and the visual arts of the region.

Until 1918, when Bukovyna was the crown land of Austro-Hungarian Empire, the influence of Austrian culture on the formation of the art of the region was significant - through the work of visiting architects, painters and sculptors, print publications and exhibitions of artistic societies. Among the educational establishments in which local artists acquired their profession at that time, the most important were the universities and the Academies of Vienna, Munich, Krakow and Berlin;

5 Міщенко I. Кераміка у творчості буковинських художників 19802000-х років. Студї мистеитвознавчі. 2010. № 2(30). С. 42-49.

${ }^{6}$ Меридіан серця : каталог / вст. ст. О. Ягодовська. Чернівці : Букрек, 1998. 40 с. ; Мистецтво Буковини : каталог. Чернівці, 2004. 64 с. 
the received education largely determined the artistic preferences of the local authors. A considerable number of Austrian sculptors worked in Chernivtsi, including Viennese sculptors, inter alia George Leizek, F. Klueg, Theodor Stundl, Anton Brenek and others; there were international competitions for the monument constructions (in particular, the competition for the monument of the Empress Elizabeth in 1907).

From 1918 to the 1940s, Bukovyna was part of Romania, which led to changes in vocational education, so the Bucharest and Prague Academies, as well as Parisian private institutions (the Academie Julian, the Jean-Paul Laurens School of Art) became popular. This coincided with the general reorientation on the figurativeness of France, and among the most widespread trends were Impressionism, Post-Impressionism and Expressionism.

Among the sculptors, whose works were shown in Chernivtsi expositions in the first third of the 20th century, were Archip Roshka, Julius Zlamal, Ioan Cardei, Ignaz Kliger, Willi Klein, Jean Leon Cosmovici, Bernard Reder, N. Svijevski, Ilarion Suhan, Ioan Syrgie and others. Today, only a few reproductions of the works of these authors can be seen in the editions of the 1920s and 1930s. Few tombstones at the Russian Cemetery in Chernivtsi made by Lavrin Kukurudza, Carl and Wilhelm Moskaljuk, and Julius Zlamal have been preserved.

Due to the Molotov-Ribbentrop Pact in 1940, Northern Bukovyna was annexed by the USSR - this prompted a rapid change in the generation of artists, since many graduates of well-known European art institutions in the interwar period and before the return of Soviet power in 1944 were forced to leave the country. Instead, a large number of graduates of art schools and institutes of the USSR, often former veterans, arrived in Chernivtsi. Right after the liberation of the country from German troops in 1944, the first art exhibition was held here.

Among the sculptors who came to Bukovyna during the 1944-1960s were graduates of the Kiev Art Institute - Antonina Tebenkova (19091976) and Lviv Institute of Applied and Decorative Arts - Anatoly Skyba (1930-2001). From the sculptors of the pre-Soviet period, only natives of the region continued to work in Chernivtsi, for instance, Ignace Kliger (born 1913, studied at the Paris Higher State School of Arts, 1972 - went to Germany) and doctor and painter Opanas Shevchukevych (1902-1972, attended the classes of the Berlin Academy of Arts in 1930).

The creativity of these masters during the 1950s - 1970s is characterized by appeal to the theme of the Great Patriotic War, the 
domestic genre (A. Tebenkova ${ }^{7}$ ), the creation of numerous portraits of the historical and cultural figures of Ukraine and the USSR republics, heroes of war and labor. The majority of the mentioned authors worked in accordance with the requirements of the art of socialist realism, creating works that were decidedly close to academic art.

Some works by O. Shevchukevych, reminiscent of his own works close to the style of expressionism of the 1920s - 1940s ("Girl's Head", 1943; decorative composition "Head of the Old Woman. Creative Power", 1948), and sculptures by A. Skyba form the exception. The works of the latter were distinguished by the dramatic image expressed in the dynamic forms of the images, which also contributed to the artist's appeal to the wooden sculpture. Among his works, the most interesting were: "Lukian Kobylitsa" (1959), "Taras Shevchenko" (1961), "Oleksa Dovbush" (1963), the monument to Olga Kobylianska in Chernivtsi (1980, co-authored with M. Miroshnichenko).

His latest work replaced the more chamber-by-volume sculpture of I. Kliger (now installed in Chernivtsi City Park). In it, A. Skyba sought to recreate the image of "Mountain Eagle", as her contemporaries called the writer. Therefore, the monument is marked by restraint and even the severity of the image, which to some extent contradicts the appearance of O. Kobylyanska herself - fragile and painful. The outline of the cape with its dynamism underlines the peculiar rootedness of the figure of the writer, giving her figure even more monumentalism.

In the 1960s - 1970s Yuriy Dzhibraev, Mykola Lysakivsky, Mykola Miroshnichenko (1936-2016, graduated from the I. Fedoriv Ukrainian Polygraphic Institute in Lviv), Dmitry Gorshkovsky (1940-2015), and graduates of the Odessa Art College and Pedagogical Institute Petro Lemsky (born 1936) and Anatoly Piontkovsky (born 1952) began to work in Chernivtsi. In addition to professional sculptors, artists from other fields of interest have periodically approached the creation of works in the field of plastics, among them Artem Prysyazhnyuk (19472017) and Ivan Vihrenko (1939-2004). The variety of schools in which the artists studied determined the differences in their creativity, the particular manner of performance of each artist.

Yuriy Dzhibraev (born 1935), a graduate of the Mukhina Leningrad Higher Art and Industrial College, worked in Chernivtsi in 1966-1981. He created memorial ensembles in honor of the fallen soldiers ("To the Memory of the Dead", 1967; “The Sorrowful Woman”, 1968) and

${ }^{7}$ Антоніна Тебенькова : проспект. Чернівці, 1973. 
numerous portraits ("Portrait of O. Kuliy", 1973); he also approached the small sculptures. In spite of the thematic component common to many authors, the works of this artist, above all the portraits, are marked by the expressiveness of holistic, succinctly resolved images, generalized forms and stylistics of which have their origins in the innovations of Soviet monumental art of the 1960s in many respects imitating artistic decisions of the period of "strict style".

Mykola Lysakivsky (1943-2010), who graduated the Kyiv State Art Institute, left a significant work accomplishment. Among his works in the 1980s - 1990s are the monument of Taras Shevchenko (co-authored with P. Lemski) and the monument to the Afghani soldiers, the memorial plaques to actor I. Mykolaychuk, theatrical figure V. Vasylko, and composer V. Ivasyuk in Chernivtsi.

Often the author uses the techniques and forms of decisions typical for Ukrainian sculpture of the late 1960s and 1970s. This is especially noticeable in the monument to the fallen Afghan warriors in Chernivtsi, which is distinguished by the almost phantasmagoria combination of features of provincial variations of monuments to the war liberators of Soviet times and Christian symbolism. The composition, modeled on "Pieta", is marked by the realistic interpretation of the figures and a somewhat excessive detailization. It is to be noted that in the competition for the construction of this monument won another sketch by the same author - more symbolic and concisely-restrained by its solution. However, later the customer pressure forced the author to use a more "understandable" and therefore the more standard version.

Among the works of this artist is a plaque dedicated to Volodymyr Ivasyuk on the house where the apartment-museum of the Ivasyuk family is located, a relief on Ivan Mykolaychuk Street (1991), in which there appears stern, with somewhat pointed features, portrait of the actor, combined with chopped, as if stamped from the mountain range, forms. The images on the sculptor's memorial plaques acquired this exacerbation in the early 1990's (a relief with a portrait of Yuriy Fedkovich). However, despite the desire to generalize the images, these works still lack the integrity of the solution.

In general, the artist's monumental plastic often seems unjustifiably over-saturated with details and symbols, but sometimes differs in the clarity of the solution (a work dedicated to the Holodomor, a memorial plaque honoring Andrey Sheptytsky in Chernivtsi etc.). The artist's easel is somewhat different in style. Chamber by sound, it is marked by a special lyricism, generalization and integrity of the overall solution. 
Despite the changing socio-political and artistic situation in Ukraine many of the mentioned artists continued to work during the 1980 s 2000 s in the usual semi-realistic manner (M. Miroshnichenko). Remarkable from this point of view is the monument to the first Metropolitan Bishop of Bukovyna, Yevgeny Hakman, installed in 2006 next to the cathedral in Chernivtsi, built during the service of the Metropolitan. The figure of the clergyman stands on a pedestal in the form of the upper part of the column, with a staff in his left hand and a crucifix in his upward right hand. The dynamic of the drapery of the outfit, inherent in the works of the sculptor, does not appear, however, to be conditioned by plastic. Like other works of this author, the monument is characterized by excessive pomposity and details, at the same time somewhat surprising by earthly proportions, and the severity of obscure forms, the general disproportion to the elongated and restrained classic forms of the cathedral.

One can compare this work with the nearby memorial plaque dedicated to E. Gakman, authored by Artem Prysyazhnyuk, in which, using traditional iconography, the artist found a complete and original, concise, linguistic formula, the embodiment of the image - concrete and generalized.

The stylistic changes in the plastic of the region became noticeable in the works of Volodymyr Gamal and Petro Hrytsyk.

Petro Hrytsyk (born 1944, studied at the Lviv Institute of Applied and Decorative Arts, since 1990 lives in New York, USA) worked in the field of monumental art, ceramics and easel painting and was a representative of the non-conformism. The artist's compositions are distinguished by their symbolic and high plastic culture.

Working in ceramics from the late 1960s to the mid-1980s, he created, for the most part, cycles of work united by a common theme or principle. Among them are four compositions of fire clay for the dining room of the Chernivtsi Organization of the Ukrainian Society of the Blind (1987), which create a complete ensemble with a wall painting by the same author. Unfortunately, for the time being, the entire ensemble, except for three ceramic layers, has been destroyed.

These works summarize the elements and phenomena that symbolize human life: a bird flies over the nest, a jug with an apple, a woman's face with an unmarked pupil (a sign of blindness) as if it is trapped in the darkness. In almost every work the author emphasizes the horizon line as a sign of earthly realities. Depicting a veil associated with the "restraint" of the blind person's world and the inability to correct something, the 
artist emphasizes her almost physically tangible weight, applying deep watering to the depths of the folds. Unlike drapery, the barely marked bulges are perceived as clouds around the clearly cut sickle of the moon; later a similar motif of eclipse will also appear in P. Hrytsyk's painting ("Eclipse", 1989).

The artist creates a plastic image of the world of a person without vision, when the perception of the environment occurs only at the touch, which feels the subtle changes of relief. The author uses a single technique for all layers - the arrangement of large symbolic images on a concave basis, which emphasizes the sense of spatial depth. The master seems to slam into the base, with broad, highly recessed contours, emphasizing the extremely simplified silhouettes of the reproduced objects. Combining a concave and convex volumes with almost subtle elevations, the artist achieves a nearly scenic design of each plane. And softer lighting effects are enhanced by a restrained, yet emotionally intense, color scheme dominated by complex green, ochre-gray, grayblue and gray-green colors.

In P. Hrytsyk's works we feel the intented balance of elements, which form a composition. This marks the layer made in the 1980s, where the simplest geometric figures with vivid colors create an emotionally rich decorative plane. The brightly expressed aesthetic of postmodernism with inherent analytics and at the same time spontaneity of emotional expression is inherent in the works of this artist.

The creative work of Volodymyr Gamal (born 1948), a graduate of the Tallinn State Art Institute, distinguished from the majority of Chernivtsi sculptors of that time. He works with various materials (bronze, sandstone, ceramics), creating both monumental works ("Angel", memorial plaque "Kobzar" in Chernivtsi, 1990s), and chamber-by-sound easel works; he also appeals to medal art.

This artist's works (plastic and graphic sheets) are distinguished by the cleanliness of the lines, the expressiveness of clear outlines and the accuracy of the silhouettes, plastic freedom and at the same time thoughtful integrity of the image. They unite massive and closed geometric shapes and the eloquence of the symbolic elements (monuments to Petro Konashevych-Sahaidachny in Khotyn, 1991; to Yuriy Fedkovich in Chernivtsi, 1995; composition "Region", 1988; "Kobzar"; "Dreams", 2001).

Deprived of narratives, V. Gamal's works are marked by conciseness and restraint of emotions, they, regardless of their size, look monumental, and the sculptor builds volumes on the contrast of convex 
and concave elements, only sometimes supplementing them with the inclusion of expressive textures.

The creative work of Petro Hrytsyk and Volodymyr Gamal attests the final transition from socialist realism, with its inherent pathosity and the regularity of formal decisions, to sculpture, in which the artist does not use a natural reflection of reality, but creates his own world, built on ancient symbols, reminiscences and complex associations.

\section{Stylistic features of Bukovynian sculpture of the late 20th - the first decades of the 21st century}

The generation of masters, whose creative path began in the late 1980s, includes Ivan Salevych and Svyatoslav Virsta.

Ivan Salevych (born 1960), a graduate of the Faculty of Monumental and Decorative and Applied Arts of the Moscow Higher Art and Industrial College (formerly Stroganovsky), became a part of the postmodern space in Ukraine, as he seeks to create not even plastic metaphors, but a new dimension of the reality. Working at the intersection of rational and associative, traditional ideas and play of contents, experimenting with the boundaries of different types of art, he organically fits into the contemporary artistic situation ${ }^{8}$.

Ivan Salevych uses reminiscences of classical culture, performing works in which everything is subordinated to formal expressiveness, and the symbol, due to its capacity, becomes the shortest way to the conciseness of the solution. The sculptor tries to capture the essence of everyday things, finding often a symbolic image inside them. In some cases, even the standard form of objects allows the artist to visualize the ambiguity of time, to give the work an unexpected journalistic sound ("Situation", 1991; "Armchair for the Ukrainian Magnate", 2015).

Made in 1990 the dramatic "Flower of Our Culture", where broken shiny black jugs and ceramic fragments with vibrant traditional painting became the incarnation of destruction and at the same time the hope of revival. In the early 1990s, an ascetic-tragic and surprisingly human "Chapel of Our Regret" struck the exposition of one of the exhibitions, in which the tragic history of Ukraine was reproduced through Christian symbolism.

In 1998-2001 appeared the expressive ornamental triptych "Symbols of Ukraine" and the lyric-joking "Flower of Our Love". In them the artist

${ }^{8}$ Іван Салевич. Скульптура : каталог / вст. ст., уклад. І. Міщенко. Чернівці : ДрукАрт, 2010. 20 с. 
transformed the world of familiar things into signs and it appears as an uncompromisingly accurate reflection of his own position. The outward strict restraint of these works suggests a tremble sadness for the lost or for what did not happen, leaving behind unspoken thoughts and feelings.

The first impetus for artistic pursuits of Ivan Salevych in the late 1980s were the achievements of artists who in the 20th century were the embodiment of plastic innovations (O. Arkhypenko, G. Moore, O. Tsadkin). Characteristic to the works of these sculptors is the interaction of the object form and environment, the desire to construct an environment in which the sculpture and subordinated to a single internally conditioned development of the plastic-spatial idea, will later become decisive in most of the works of this author.

The most characteristic features of this early period are the conciseness of the holistic, precisely outlined silhouette, sometimes supplemented by engraving ("Egyptian Reminiscences", 1993), the rhythmic visibility of a composition built on a comparison of vertical and horizontal volumes ("Grief"), or the dominance of the upright element ("Prayer", "Birth of Venus"). In the sculpture of the mentioned period the author often resorts to polychromy, finding inspiration, in particular, in the samples of ancient Egyptian and ancient Greek plastics, using engobe toning and painting ("Podolyanka", 1988, "Pharaoh", 1989).

From the late 1980s the artist approaches to the creation of compositions from individual elements, which results in the interaction of plastic elements and the environment. The composition "My Childhood Islands" (1988) distinguishes among the other works of the late 1980s, with its touching and clear embodiment of dreams and memories and a complex space which arises from the unification of individually arranged multiple-scale elements.

A similar principle of solution will be found repeatedly in the plastics of the 1990s. Lapidary of plane forms, made from untreated iron, dissected by its own wings or terrestrial meridians, transfers the destruction of elan in "Icarus" (1991); and the placement of the work under the viewer's feet enhances the tragic sound of ancient myth. In "Great Parturient Woman" 1997, the very separation of forms gives the sculpture a great deal of dimension and symbolism, transforming it into a personification of birth-division. By limiting the image to a small amount of detail, the artist uses unexpected angles and sharpens the forms. $\mathrm{He}$ strives to reproduce the physical and emotional tension of the action, successfully using not only plastic but also a variety of textures. 
Over the time, the use of ancient symbols (tree of life, phallic symbols, etc.) significantly enriches the plastic-shaped language, which leads to the formation of symbolic parallels, variability in the resolution of established images, and at the same time reflects a more complex model of worldview. In the work "The Hermit" (1991), the form itself dictates the ambiguity of reading the work - the spiritual and physical perception of the idea of seclusion and loneliness, restraint of human impulses, the transformation of a person into a bird with wrapped wings.

The motif of the "tree of life" acquires a somewhat unusual embodiment with a rather rigid interpretation of the form in "The Eternal Tree" 1998, and later reads in the symmetrical lines of "Women-Tree" (2000).

Sometimes the artist seems to revert to already used plastic ideas, interpreting them in a new way. Thus, the theme of "Original Source" (1988) will later be recognized in "The Holy Family" (2000), getting rid, however, of the lyrical tenderness of an early work. Thus, "The Hermit" of the early 1990s will echo with the monumental "Dedication to the Opishny" in 2000, established in the well-known ceramic cell in the Poltava region. The underlined male principle in it is organically combined with the symbolic depiction of the layers of the past epochs, and the peasant's visor becomes a nimbus, sanctifying the act of creation.

Erotic motives are also present in Ivan Salevych's work. Occasionally provocative and outrageous, such works are marked by sharp expressiveness of the outline and unexpected frankness ("River", 1988; "Eve", 1991; graphic sheets; spatial composition "Fruits", 2006). At the turn of the centuries, a number of variations on the theme of "Graces" and "Muses" appeared with the atypical for other works of these years classic restraint of the forms.

The soft and at the same time elastic plastic, in comparison to the clear outlines of sculpture of the late 1980s, distinguishes the "Steppe Singer" (2000). The feeling of the melody of melancholic singing and the impression of organic growth of the inclined female figure from the ground, is conveyed by the floating contours and expressed by the rhythmic image of grass on the bottom. All this is exacerbated by the association with the medieval stone sculptures of the Ukrainian steppes.

A similar motif occurs in the "Scythian Madonna" (2000), which, however, seems too amorphous in the form. The same fluidity and somewhat unexpected for the fine plastic monumentality is present in "Demeter", created in 1998. 
Since the early 2000s, more plane- graphic elements appear in the artist's easel work, and the silhouette begins to play perhaps the most important role. The works themselves by their form are increasingly drawing near to the design objects ("Caryatid of the Sun" (2004), "Necklace for the Goddess" (2005), "Dance of the Kupala Night" (2000).

The sophistication of the concise and precisely found image distinguishes the monumental works of the artist. Due to the clarity and purity of the plastic language, the artist, conceiving the atmosphere of the Chernivtsi suburbs, succeeds to delicately inscribe the monuments and memorial boards to the existing architectural outlines of the buildings, without destroying, but completing the appearance of the old city (memorial plaques dedicated to conductor Bogdan Kryzhanivsky, actor Boris Borin, storyteller Eliezer Steinbarg).

The elongated silhouette of Archangel Michael, constructed in honor of the Bukovynian Kuren Soldiers in Chernivtsi (1995), is an embodiment of the idea of protection and bravery and combines the motives of Oranta and the archistratege. The restrained rigor of the figure is visually complemented by the ornaments with viburnum motifs, patterned inscriptions on the shield, and intricately profiled pedestal.

On the contrary, the dynamic space of the monument to the poet Paul Celan in Chernivtsi (1992) is formed by interconnected volumes of the head, shoulders and moon wings, and is associated with the complex structure of his poetry, the dramatic fate and the semi-fantastical world of the writer's imagination.

The tendency to interpret classical plots and iconographic schemes is also present in the sculpture "The Return" created on the sculpture symposium in Vyshgorod in 2008. The starting point of it was Rembrandt's motive of the Prodigal Son, shaped to the inherent to this author's works plastic formula. In the emphasized geometry of the sculptural composition, the internal stress of the original work is preserved due to the successfully found correlation of mass and the clarity and accuracy of the laconic overall silhouette.

The postmodernism tendencies appeared most emphatic in I. Salevych's last monumental work - a sculptural composition dedicated to the Holodomor, assembled in Chernivtsi in 2018. Unusual by decision, devoid of literary basis, the composition is built on associations and signs. Placing on the slopes three huge cubes of polished black granite on the sides of which were carved the words "Holodomor", "Genocide", "Repression", and an omen for Ukraine dates of these events, the sculptor sought to emphasize the incompatibility of the artificially 
created repressive machine and the changing outlines of the natural forms of the square. The cubes, which enter the ground in one of the corners, are surrounded by black metal pillars, on top of which gilded spikelets are placed. These pillars symbolize both the cereal stalk, beyond the reach of the dying of starvation, and the columns of memory or the figures of the dead. At once, the monument gives rise to a sense of anxiety through the false impression of the instability of the stones, reminding us of the need to create a world in which the return to the tragic events of the past is impossible.

The desire to fully realize themselves now leads the sculptors to active interaction with other cultural manifestations, in particular, through the organization of various actions, the formation of a modern art space, in which art is an integral and important component. This is how the "Folkmodern" triennial has been going on since 2009 in Chernivtsi. The project seems not to be coincidental for the artist, in the work of which for many decades, there have been numerous attempts to combine folk culture and modern forms of professional art, in particular through the appeal to body art ("Jaril's Spouse" in the play "The Destiny of the Sun", 2003) and the creation of numerous installations. Sensitivity to the processes that take place in the art of today, combines in the artist's work with a logical sequence of changes, manifestations of which are noticeable at different stages of his work, testifying to the unrandomness of his path and confidence in his own beliefs.

The creativity of Svyatoslav Virsta (born 1962), who studied at the Chernivtsi Vocational College \# 5, is characterized by an appeal to archetypes, the use of the most ancient, common for the entire humanity Neolithic symbols, and the desire to find a concise and comprehensive system of concepts, enriching the modern plastic figurative language. In his works there is a desire to move away from the reality, familiar for past times of reproduction - to the associations, the significance of the image. The emergence of numerous reminiscences of sculptures of the primitive age is connected to that ("Paleolithic Beauty", 1998; "Baba", 2003; "Lord of the Blue Mountains", 2000).

Independent, non school, mastering of traditional art made it possible to choose from it the preferences most suitable for the artist. Almost in the same way the sculpture was mastered by the artist through the work of the formator, through the touch, the development of technology and the creation of forms used by the authors, different in their artistic directions, through some sort of "dispute" with them. Such are the early works as "Butterfly" (1994), and "The Singing Boy" (1994). 
As a result of the elaboration of the plastic ideas of avant-garde art of the first third of the 20th century, arise composed with the simplest geometric volumes, supplemented by the flat overhead details "Woman in a Skirt" and poetic, made on the contrasts of convex and planar elements "Fluidity" (both 1992). Subsequently, a similar principle of solution will appear in the "Lullabies for Me" (1999), whose soft-convex outlines will pass into concave geometric planes, forming sharp-cut diagonal intersections of shapes and each time differently revealing themselves from different points of view.

I. Salevych and P. Hrytsyk create works from a layer or by the means of pottery, therefore Svyatoslav Virsta uses pouring from a slip in gypseous form. This allows him to achieve a special plastic expression of the works in which halftones of illumination outline a volume that is only gradually and often unexpectedly revealed when the sculpture is rotated.

Characteristic for the artist's work is the creation of works in peculiar cycles, as if the idea does not leave the artist, waiting for the fullest embodiment. This is how numerous torso of the late 1990s and early 2000 s were created, in which the sculptor, slightly changing the proportions, seeks to find perfection ("Two Graces", 1997; "Eve", 1998).

Svyatoslav Virsta is attracted to the expressiveness of the plasticity of the human body, which he interprets using classic designs and transforming, seeking to convert into a clear and concise sign.

Distinctive in sound were male figures made in the 1990s. Precisely outlined, closed silhouettes of the works, expressed in polychromy and complemented by the inclusion of texture, reproduce once the sense of effective creative energy ("Poet"), once the strict loneliness or indifference ("Man in the Coat" (1992) and "The Absent" (1996). The latter work is surprising by the unexpected, not peculiar to the artist publicistic, becoming the embodiment of protest against indifference, the personification of which is the figure of a man who always turns his back on people.This perception is enhanced by the contrast of black and red tint with precisely found accents.

In the closed form of "The Dream of Small Homo Sapiens" (2000), the reality of the vision is paradoxically combined with the generality of the sign, and the barely perceptible transitions of the form are softened by the matt-porous texture of the clam. It is this work that marks the principles important to the artist when the plastic embodies not the plot, but the concept: "I never molded people, but - a silence, a poetry" (Svyatoslav Virsta). 
In the works of the 2000s often appears the motif of loneliness, and the artist's characteristic geometrical shapes acquire the outline of the front stella, emphasizing the stiffness of the man-stone, its doom ("Loneliness"). Children's Game of filaments, which no one can take off their fingers, appears here as the embodiment of loneliness. Freezed, as if forced to stop in their own motion, the hands are incapable of breaking the bundle of loneliness, combined with the symbol of feminine origin a truncated rhombus - a sign of unrealized nature.

The juxtaposition of the man to everything that surrounds him, and to what he is a part of, is evident in the work "Twilight" (2007). Somewhat unusual for its spatial solution, this work resembles a subjunctive landscape, the generalized rounded masses of which may be both landmarks of the cities or symbols of the forests or mountains. Here, the amorphous mass that envelops the person gradually turns into a graphic shadow, similar to her, but larger in size. Thus, plastic creates a landscape image rare in this art, combined with the current theme of unity and at the same time the juxtaposition of individuality and its surrounding.

Subsequently, in the plastic of the artist, performed in different materials, two directions will determine that will continue to exist in parallel - the transformation of the human figure into a kind of ornament with emphasized rhythmic of clear geometric elements and the embodiment of images-associations reflecting a certain state. This is especially noticeable in the works of the early 2010s, where subtle nuances of emotion are organically combined with the programmed monumentality of the solution. These traits are noticeable in particular, in the non-standard solution of the composition "One" ("Dedication to Mykola Buchko", 2012), where a portrait of a particular person becomes a dramatic image of a generation. The image of the poet consists of architectural elements and fragmentary images (head, hands), and almost gothic expression is felt in proportions and sharp forms.

The work contrasts with the lyrical and ironically-performed work "Grigory Skovoroda", executed decades ago, who, in the form of a teenager with a laurel wreath on his head, sits on a huge cube (the embodiment of reality), reminiscenting the philosopher's famous saying: "The world caught me, but did not catch me".

Bukovynian sculpture of the last decades presents a considerable variety of approaches to solving the image of the poet - from traditionally pathos ("Olga Kobylyanska" by A. Skyba, "Taras Shevchenko" by M. Lysakivsky) or lyric-sentimental figures ("Mihai 
Eminescu" by D. Gorshkovsky) to expressive, dramatic incarnations of the creative personality, in which the manifestations of the art of the postmodernism ("Yuri Fedkovich" by V. Gamal, "Paul Celan" by I. Salevych, "One" by S. Virsta) are tangible.

Same as Volodymyr Gamal and Ivan Salevych, Svyatoslav Virsta has not limited himself to sculpture, but is also working in painting and created a conceptual series of paintings "I am a Formula". In them, through the sign (in this case, a figure), the author tells not only about universalities, but also about the fate of Ukrainian mathematicians whose formulas are used in the composition.

Svyatoslav Virsta also co-authored the idea of the All-Ukrainian Triennial of Abstract Art "ART-AKT", which united masters of fine and decorative art in an effort through form, tone and color, organize into a composition, to tell about their own ideas about the universe and the emotional state of society. In 2019, the Fourth Triennial was held, once again demonstrating that the art of Ukraine gradually freed itself from the non-freedom of thematic and formal restrictions of socialist realism, choosing a model of development based on the absolutization of selfcontained elements of the visual image.

\section{CONCLUSIONS}

Bukovynian sculpture from the mid-1940s to the present fully reveals the specifics of the fine arts development of the region, demonstrating a rather rapid departure from the traditional Soviet-era illusory realism, illustrative and defined range of themes to the multilayered content and ambiguity of perception, transformation of plastic ideas of classical art and art of postmodernism.

During the 1940s - mid-1980s, individual manifestations were sometimes offset by the thematic direction of the works shared by different authors, with rather rigid requirements for their plastic solution. Since the late 1980s not only an extension of the themes of the works becomes noticeable, but also the diversity of formal solutions, the desire to absorb the ideas of modernism and postmodernism.

A sharp burst of publicistic in the sculpture of the late 1980s - early 1990 s, driven by the changing social-political situation in Ukraine, the desire to comprehend the ambiguous perception of Ukraine's dramatic history, will eventually give in to the search for non-trivial plastic ideas.

Representative are the works of such masters as Volodymyr Gamal, Ivan Salevych and Svyatoslav Virsta, whose creativity today largely determines how the Bukovynian sculpture will develop, gradually 
moving away from literary-based works to the complex in imagery, built on the associations and artistic parallels plasticity of postmodernism.

\section{SUMMARY}

The purpose of this paper is to analyse the development of sculpture on the territory of Bukovyna from the middle of the 20th century to the beginning of the 21 st century. The methodology of this study includes the complex application of various methods: historical, comparative, biographical and art history analysis. The use of the above methods allows us to analyse thoroughly the progress of fine arts in the region.

The scientific novelty of the obtained results is in the coverage of artistic processes in Bukovyna, which have not been adequately reflected in the scientific literature, the introduction of scientific names of artists and the analysis of the stylistic peculiarities of their works. The study of this topic makes it possible to consider objectively the creative work of sculptors of different generations and various artistic preferences, to trace the influence of the social-political situation of a particular historical period on artistic practices and to identify which world view principles and stylistic tendencies prevail in Bukovynian sculpture during the 20 th - the beginning of the 21 st century.

The development of the sculptures in the region from the mid-1940s to the present shows a gradual departure from the traditional for Soviet art thematic direction and illusory realism, the depersonalization of the characters and usage of the common stamps to works with multilayered content and ambiguity of perception.

The search for such masters as Volodymyr Gamal, Ivan Salevych, Svyatoslav Virsta at the beginning of the 21st century determines how the sculpture and fine art of the region will develop in general, moving away from works based on literary plots and recognizable, standardized images and compositional schemes, to the complex content constructed on associations and artistic parallels, postmodernism plastics.

\section{REFERENCES}

1. Анатолій Георгійович Скиба : каталог / авт. К. Валігура. Чернівці, 1980. 48 с.

2. Анатолій Скиба : проспект виставки творів / авт. Т. Удіна. Чернівці, 1970.

3. Антоніна Тебенькова : проспект. Чернівці, 1973.

4. Дугаєва Т. Скульптор, доктор медицини Опанас Шевчукевич. Чернівці : Зелена Буковина, 2002. 88 с. 
5. Іван Салевич. Скульптура : каталог / вст. ст., уклад. I. Міщенко. Чернівці : ДрукАрт, 2010. 20 с.

6. Меридіан серця : каталог / вст. ст. О. Ягодовська. Чернівці : Букрек, 1998. 40 с.

7. Мистецтво Буковини : каталог. Чернівці, 2004. 64 с.

8. Митці Буковини : Енцикл. довід. / авт.-упоряд. Т. Дугаєва, I. Міщенко. Т.1. Чернівці : Золоті литаври, 1998. 128 с.

9. Міщенко I. Кераміка у творчості буковинських художників 1980-2000-х років. Студії мистецтвознавчі. 2010. № 2 (30). С. 42-49.

10.Юрій Джибраєв : проспект виставки творів / авт.-упоряд. Т. Удіна, Є. Удін. Чернівці, 1970.

\section{Information about the author:}

Mishchenko I. I.,

Candidate of Art Sciences, Associate Professor at the Department of Artistic Expertise National Academy of Culture and Arts Management 9, Lavrska Str., Kyiv, Ukraine 